\title{
Division of Extramural Activities
}

National Cancer Institute

\section{Source}

National Cancer Institute. Division of Extramural Activities. NCI Thesaurus. Code C18753.

A division within the National Cancer Institute that coordinates the scientific review of extramural research for consideration of funding, and provides systematic surveillance after awards are made. 